\title{
The climate in The Netherlands during the Younger Dryas and Preboreal: means and extremes obtained with an atmospheric general circulation model
}

\author{
H. Renssen \\ Netherlands Centre for Geo-ecological Research (ICG), Faculty of Earth Sciences, Vrije \\ Universiteit Amsterdam, De Boelelaan 1085, NL-1081 HV Amsterdam, The Netherlands, \\ renh@geo.vu.nl, phone +31 20 4447357, fax +31 20 6462457, \\ and \\ Institut d'Astronomie et de Géophysique Georges Lemaître, Université Catholique de \\ Louvain, 2 Chemin du Cyclotron, B-1348 Louvain-la-Neuve, Belgium, \\ renssen@astr.ucl.ac.be, phone +3210478501
}

Manuscript received: September 2000; accepted in January 2001

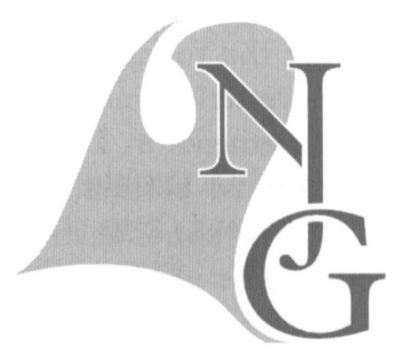

\begin{abstract}
The shift from the coldYounger Dryas phase to the relatively warm Pre-boreal at $\sim 11.5$ thousand years BP occurred within 50 calendar years and represents a clear example of rapid climate warming. Geologists and palaeo-ecologists have extensively studied the impact of this shift on the environment in The Netherlands. The global atmospheric general circulation model of the Max-Planck-Institute for Meteorology is applied to perform simulations of the Younger Dryas and Pre-boreal climates. Here detailed results are presented for the grid-cell representing The Netherlands, providing quantified estimates of climatic means and extremes for both periods. The results suggest that the Younger Dryas climate was characterised by cold winters (temperatures regularly below $-20^{\circ} \mathrm{C}$ ) and cool summers $\left(13-14^{\circ} \mathrm{C}\right.$ ), with a high inter-annual variability, strong fluctuations in temperature, frequent storms and snowfall from September to May. The Pre-boreal climate was a 'continental' version of present-day climate, with cooler winters, warmer summers $\left(\sim 2^{\circ} \mathrm{C}\right.$ difference) and more snowfall, but lower wind speeds. Also, the Pre-boreal climate was wetter than the present and Younger Dryas climates. The main driving factors were the low temperatures of the partly sea-ice covered $\mathrm{N}$ Atlantic Ocean and the insolation that was very different from today, with more incoming solar radiation during summer $\left(+30 \mathrm{~W} / \mathrm{m}^{2}\right)$ and less during winter $\left(-10 \mathrm{~W} / \mathrm{m}^{2}\right)$. The presented detailed results could be valuable for interpreting palaeo-environmental records and for modelling studies on sedimentological processes during the Late Quaternary.
\end{abstract}

Keywords: climate change, GCM, Pre-boreal, The Netherlands, simulation, Younger Dryas

\section{Introduction}

The last glacial-interglacial transition at $\sim 11.5 \mathrm{cal} \mathrm{ky}$ BP (thousand calendar years before present) marks one of the most drastic phases of climate change in Europe during the Quaternary (e.g., Taylor et al., 1993). During this shift from the Younger Dryas (YD, 12.7-11.5 cal ky BP) phase to the Pre-boreal (PB, $\sim 11.5-8.5 \mathrm{cal} \mathrm{ky} \mathrm{BP}$ ) average annual temperatures in NW Europe increased by at least $10^{\circ} \mathrm{C}$ within a few decades (e.g., Brauer et al., 1999; Renssen \& Isarin, 2001). This transition has been extensively studied, as it represents a clear example of rapid climate warming, thus providing important information on the be- haviour of the geo-system during times of climate change.

Certainly, the environment of The Netherlands during the YD and $\mathrm{PB}$ is the subject of numerous papers. The vegetation development has been recorded in more than 250 pollen diagrams since the 1950's (e.g., van der Hammen, 1952; Wijmstra \& de Vin, 1971; Cleveringa et al., 1977; van Geel et al., 1980/81; Bohncke et al., 1987; Hoek 1997a; see Hoek 1997b for complete reference list). As reviewed by Bohncke (1993) and Hoek (1997b), in The Netherlands the park-like YD vegetation with heath and scattered birch, pine and juniper trees was replaced in the PB 
by birch forest and later pine forest. Moreover, many papers are published that deal with the geomorphology and sedimentology in The Netherlands during the YD and PB. These studies may be subdivided into studies on fluvial sediments (e.g., Vandenberghe et al., 1987; Weerts \& Berendsen, 1995; Kasse, 1995a; Huisink, 1997), aeolian deposits (e.g., Maarleveld, 1961; Vandenberghe, 1991; Kasse, 1995b) and periglacial phenomena (e.g., Maarleveld, 1976; De Groot et al., 1987; Bohncke et al., 1993; Isarin, 1997). The reconstructed changes may be summarised as follows: in The Netherlands rivers changed from highenergetic braided (YD) to low-energetic meandering (PB), high aeolian activity as recorded during the YD diminished in the $\mathrm{PB}$, and discontinuous permafrost present in the YD disappeared in the PB.

Palaeo-environmental data are also used to reconstruct the special climate conditions themselves, which are the main cause of the environmental changes at the YD-PB transition (Bohncke, 1993; Vandenberghe, 1995; Isarin, 1997; Isarin et al., 1997; Isarin \& Bohncke, 1999). Reconstructions for the YD-PB transition indicate a $\sim 3^{\circ} \mathrm{C}$ increase in summer temperatures (from $12^{\circ} \mathrm{C}$ to $15^{\circ} \mathrm{C}$ ) and a much stronger $\sim 18^{\circ} \mathrm{C}$ increase in winter temperatures (from $-18^{\circ} \mathrm{C}$ to about $0^{\circ} \mathrm{C}$ ) (Renssen and Isarin, 2001). Likewise, effective precipitation (i.e. P-E) values in The Netherlands appear to have increased in the YDto-PB transitional period (Bohncke, 1993). Surprisingly however, the wind direction appears to have been south-westerly throughout the period of interest and not easterly as might be expected from an analogy with present-day cold winter conditions (Isarin et al., 1997). These reconstructed climatic conditions have been found to be consistent with experiments performed with atmospheric general circulation models (Renssen \& Isarin 1998; 2001). So far, emphasis has been on the mean climate (average yearly, summer and winter temperatures, mean wind direction), as this state is believed to have been best registered in the proxy data. However, in addition to this mean climate state, the extremes of climate are also of interest, as they are likely to have had an important influence on the environment. For instance, extreme storm events probably had a strong effect on aeolian sedimentation and fluvial activity. It is, however, difficult to make estimates of these extreme states from the geological archive. Climate models could be helpful, as they simulate effectively atmospheric variability on a wide range of temporal scales (i.e. days to years), thus providing information on the frequency and occurrence of certain events and the year-to-year variability. It should be realized that extreme events simulated by climate models may only be of an indicative nature, since the simulated period of years is usually too short to obtain reliable estimates. For a thorough review of the use of climate models in palaeo-climatology, including model-data comparisons, the reader is referred to Isarin and Renssen (1999).

In this paper additional detailed climate model results on the YD and PB climates in The Netherlands are presented. These results are obtained with the ECHAM4-T42 atmospheric general circulation model (AGCM) of the Max-Planck-Institute for Meteorology. The objective is to give a more complete overview of the changing climate during the YD-PB transition in The Netherlands by providing quantified estimates of important climate parameters, such as minimum and maximum temperatures and the frequency of snowfall and storms. These detailed results could be valuable for interpreting palaeo-environmental records (e.g., Hoek 1997a, b) and for modelling studies on sedimentological processes during the Late Quaternary (e.g., Leeder et al., 1998; Bogaart \& van Balen, 2000).

\section{Methods}

\section{The Model}

The ECHAM4 (European Centre-HAMburg) AGCM with T42 resolution ( 2.8 degrees latitudelongitude or $\sim 260 \mathrm{~km}$ ) is applied to carry out experiments. This three-dimensional model (19 vertical levels) simulates the global atmospheric circulation, including directly related climatic variables as temperature, wind strength and direction, precipitation and evaporation. ECHAM4 includes both an annual and a diurnal cycle (see DKRZ, 1994 for details). The model is capable of simulating a modern climate that corresponds with observations in most cases (Roeckner et al., 1996). Nevertheless, several errors have been recognised. A known model bias for W Europe includes the tendency to simulate anomalously high summer temperatures $\left(+1^{\circ} \mathrm{C}\right.$ difference with observations) and to underestimate summer precipitation (see Roeckner et al., 1996). It should be realised that the ECHAM4-T42 model is designed to simulate climate at a sub-continental-to-global scale ( $>1000$ $\mathrm{km}$ ), making it less suitable for regional-to-local climate studies $(<500 \mathrm{~km})$. However, the AGCM results presented in this study are, so far, the only source of quantitative detailed estimates available for the YD and PB climates. Moreover, as shown in the results section, the model performs surprisingly well 
when the grid-scale (i.e., $\sim 250$ by $250 \mathrm{~km}$ ) results are compared with modern observations.

\section{Experimental design}

In this paper simulations of the $\mathrm{PB}$ and YD climates (called PBexp and YDexp) are presented together with a control experiment of present climate (CTRL) for comparison. The duration of the experiments was 16 (CTRL) and 12 (PBexp and YDexp) years. All model results shown are based on results from the last 10 simulated annual cycles of 360 days each with an output interval of 12 hours. In CTRL present-day boundary conditions are prescribed, including insolation, concentration of greenhouse gases, annual cycle of sea surface temperatures (SSTs), surface elevations, land-sea-ice distribution and land surface characteristics such as albedo and vegetation cover. These boundary conditions are altered in PBexp and YDexp to simulate the conditions of the corresponding periods (see Table 1). YDexp should be considered as a representation of the entire YD, as the time-control of the boundary conditions is insufficient to allow for a distinction between different phases within the YD (cf. Bohncke, 1993).

\section{Sea surface conditions}

Most of the sea surface conditions prescribed in the $\mathrm{PB}$ and YD experiments are based on palaeo-oceanographic evidence, such as SST and sea-ice reconstructions derived from planktonic foraminifera and diatoms. In PBexp modern ocean conditions were defined, i.e. identical to those used in CTRL. This is in agreement with the reconstructions of Schulz (1995). In YDexp, a cooled N Atlantic ocean was prescribed based on SST reconstructions of Sarnthein et al. (1995) and model results (Schiller et al., 1996). The reader is referred to Renssen (1997) for a full description of the usedYD SSTs. Compared to CTRL, SSTs were lowered by $8^{\circ} \mathrm{C}$ in the $\mathrm{N}$ Atlantic at $50^{\circ} \mathrm{N}$. As a result of this cooling, the sea-ice margin was positioned further south $\left(\sim 55-60^{\circ} \mathrm{N}\right.$ in winter, $\sim 70^{\circ} \mathrm{N}$ in summer) than in the control experiment $\left(\sim 80^{\circ} \mathrm{N}\right.$ in winter, $\sim 75^{\circ} \mathrm{N}$ in summer), which is in agreement with the reconstructions of Koç et al. (1993). In the Atlantic south of $30^{\circ} \mathrm{N}$ present-day SSTs were defined, thus assuming that no ocean cooling took place during the YD in the tropics (cf. Schulz, 1995; Thunell \& Miao 1996). In the N Pacific a cooling of $2^{\circ} \mathrm{C}$ was prescribed north of $40^{\circ} \mathrm{N}$ (cf. Kallel et al., 1988; Mikolajewicz et al., 1997). It should be noted that the results of AGCM climate simulations are quite sensitive to prescribed SSTs and sea-ice cover. To validate our model results, we compared simulat-
Table 1. Summary of experimental design with the most important boundary conditions mentioned (' $k$ ' denotes thousand cal years $\mathrm{BP})$. The atmospheric concentrations of $\mathrm{CO}_{2}(\mathrm{ppm}), \mathrm{CH}_{4}(\mathrm{ppb})$ and $\mathrm{N}_{2} \mathrm{O}$ (ppb) are based on Antarctic ice core analyses (e.g., Raynaud et al., 1993).

\begin{tabular}{|c|c|c|c|}
\hline \multirow{2}{*}{$\begin{array}{l}\text { Boundary } \\
\text { conditions }\end{array}$} & \multicolumn{3}{|l|}{ Experiments } \\
\hline & $\begin{array}{l}\text { CTRL } \\
\text { Modern }\end{array}$ & $\begin{array}{l}\text { PBexp } \\
\text { 'Preboreal' }\end{array}$ & $\begin{array}{l}\text { YDexp } \\
\text { 'Younger Dryas' }\end{array}$ \\
\hline SSTs + sea ice & $0 \mathrm{k}$ & $0 \mathrm{k}$ & $\begin{array}{l}\text { YD in N Atl. } \\
-2^{\circ} \mathrm{C} \text { in } \\
\text { N Pacific }\end{array}$ \\
\hline Ice sheets & $0 \mathrm{k}$ & $11 \mathrm{k}$ & $12 \mathrm{k}$ \\
\hline Insolation & $0 \mathrm{k}$ & $11 \mathrm{k}$ & $12 \mathrm{k}$ \\
\hline $\mathrm{CO}_{2} / \mathrm{CH}_{4} / \mathrm{N}_{2} \mathrm{O}$ & $353 / 1720 / 310$ & $260 / 720 / 270$ & $246 / 500 / 265$ \\
\hline $\begin{array}{l}\text { Vegetation } \\
\text { Parameters }\end{array}$ & $0 \mathrm{k}$ & $\mathrm{PB}$ & YD \\
\hline
\end{tabular}

ed air temperatures forYDexp and PBexp with reconstructed values for Europe. In both cases, this comparison produced a mismatch for coastal regions of Europe, suggesting that the Atlantic Ocean was cooler during the $\mathrm{PB}$ and $\mathrm{YD}$ than prescribed in the two experiments (Renssen \& Isarin, 1998; 2001). The PB SSTs were probably $1-2^{\circ} \mathrm{C}$ lower than prescribed, whereas the YD winter sea margin was probably positioned at $50-52^{\circ} \mathrm{N}$ instead of $55-60^{\circ} \mathrm{N}$ as in YDexp.

\section{Insolation and greenhouse gases}

The insolation was altered according to Berger (1978), resulting in - compared to present - more incoming solar radiation during summer and less during winter. At $50^{\circ} \mathrm{N}$, the anomalies compared to CTRL are $+34 \mathrm{~W} / \mathrm{m}^{2}(\mathrm{~PB})$ and $+32 \mathrm{~W} / \mathrm{m}^{2}$ (YD) for July and $-11 \mathrm{~W} / \mathrm{m}^{2}(\mathrm{~PB})$ and $-10 \mathrm{~W} / \mathrm{m}^{2}(\mathrm{YD})$ for January. Furthermore, the atmospheric concentrations of three greenhouse gases were lowered compared to their modern values in CTRL: $\mathrm{CO}_{2}, \mathrm{CH}_{4}$ and $\mathrm{N}_{2} \mathrm{O}$ (see Table 1). The values are based on analyses of air trapped in Antarctic Ice cores (Raynaud et al., 1993; Barnola et al., 1994; Blunier et al., 1995; Flückiger et al. 1999). It should be noted that the dominant part of the greenhouse gas forcing is already incorporated in the prescribed SSTs and sea-ice (cf. Renssen, 1997). Therefore, the expected effect of the changes in greenhouse gas concentration is small compared to that of a cooled ocean surface and insolation.

\section{Topography and land-surface characteristics}

In PBexp and YDexp the topography was changed following Peltier (1994) to account for the presence of the Scandinavian and Laurentide ice sheets (see Renssen and Isarin, 2001). The ice-sheet extension is 
similar in both experiments, whereas the elevation is lowered by a few hundred meters in PBexp compared to YDexp. In addition, sea-cells in the North Sea and Bering Strait regions were converted to land-cells in agreement with sea level reconstructions (e.g., Fairbanks, 1989). Consequently, in both palaeo-experiments the location of The Netherlands was more 'continental' than in the control simulation. Moreover, the characteristics of the land-surface were altered to account for the differences in vegetation. In ECHAM4 vegetation is not dynamically included, but described through a few parameters that are kept constant during a simulation. These parameters are the leaf area index, surface albedo, roughness length, vegetation cover and forest cover (Claussen et al., 1994). The parameters for PBexp and YDexp were altered based on vegetation reconstructions of Adams (1997). The reader is referred to Renssen \& Lautenschlager $(2000)$ for a detailed description of the followed procedure. Furthermore, in YDexp a simple parameterisation of permafrost was added, implying frozen subsoil and a permanent high water table in regions where permafrost existed during YD (Renssen et al., 2000a).

\section{Results}

\section{Introduction to results presented}

In this section model results for the grid cell representing The Netherlands (borders at 50.2 and $53.0^{\circ} \mathrm{N}, 4.2$ and $7.0^{\circ} \mathrm{E}$, see DKRZ, 1994) are shown in two different ways. First, simulated results of CTRL are compared with modern observations to evaluate the model performance. Second, the results for PBexp and YDexp are presented, which in a later stage are compared with climate reconstructions based on proxy data. The modern measurements are for the reference period 1961-1990 and are derived from five meteorological stations in The Netherlands, i.e. De Bilt, Vlissingen, Eelde, De Kooy and Beek (Krijnen \& Nellestijn, 1992). These stations give a good representation of the various conditions within The Netherlands, varying from coastal (Vlissingen and De Kooy) to relatively inland locations (Eelde, Beek and De Bilt). Besides annual and monthly means, also frequencies are presented, such as the occurrence of days with frost or with more than $10 \mathrm{~mm}$ precipitation. It should be noted that the model results are based on 10 years instead of the reference period of 30 years. The length of the experiments was restricted to save expensive computing time. It is realized that this restriction may lead to underestimation or overestimation of the frequency of extremes. How- ever, it is assumed in this paper that the results of 10 years are sufficient to make a reasonable estimate of climate variability.

\section{Modern climate: $C T R L$ vs. measurements}

\section{Temperature}

The model gives a reasonable representation of the present surface temperature, although it somewhat overestimates the mean summer temperatures. Figure 1a shows that CTRL produces values for May to August that are up to $1.4^{\circ} \mathrm{C}$ higher than any of the stations, causing the yearly average temperature also to be slightly higher $\left(10.1^{\circ} \mathrm{C}\right.$ compared to a range of 8.6 to $10.0^{\circ} \mathrm{C}$ ). As noted earlier, these relatively high summer temperatures in W Europe are a known deficiency of the model (Roeckner et al., 1996). For September to April the model result falls within the range of values measured at the 5 stations, ranging from $2.8^{\circ} \mathrm{C}$ in January to $15.4^{\circ} \mathrm{C}$ in September. As shown in Table 2, the frequencies of events also correspond to observations. The frequency of "ice" days (mean daily temperature below $0^{\circ} \mathrm{C}$ ) and of days with "severe" frost (minimum temperature below $-10^{\circ} \mathrm{C}$ ) corresponds with the measurements, as well as the occurrence of days with a maximum temperature reaching $25^{\circ} \mathrm{C}$.

\section{Wind speed}

The simulated wind strength corresponds to data given for the five stations (Fig. 1b). For October to March, the model produces a wind speed regime that corresponds with the values of coastal stations ( 6 to 7 $\mathrm{m} / \mathrm{s}$ ). As noted for temperatures, the simulated wind conditions during summer appear less realistic, with wind speeds that are lower ( 4 to $5 \mathrm{~m} / \mathrm{s}$ ) than those for the coastal stations $(6 \mathrm{~m} / \mathrm{s})$. The calculated frequency of high wind speed events - days with wind speed reaching $6 \mathrm{Bft}$ or $10.8 \mathrm{~m} / \mathrm{s}$ - is $9 \%$ (see Table 2), a value that is similar to that of the inland stations of Eelde (11\%) and Beek (8\%).

\section{Precipitation, snowfall and effective precipitation (P-E)}

The model clearly overestimates precipitation during January to March and produces an underestimation during July to November (Fig. 1c). The simulated anomalously low summer precipitation is a known model deficiency (see methods section and Roeckner et al., 1996). This underestimation during summer is not fully compensated for by the high winter values, so that the mean annual precipitation sum in CTRL is somewhat lower than observations (i.e., $698 \mathrm{~mm}$ opposed to a range of 731 to $802 \mathrm{~mm}$ ). This comparison suggests that one should be cautious with the re- 

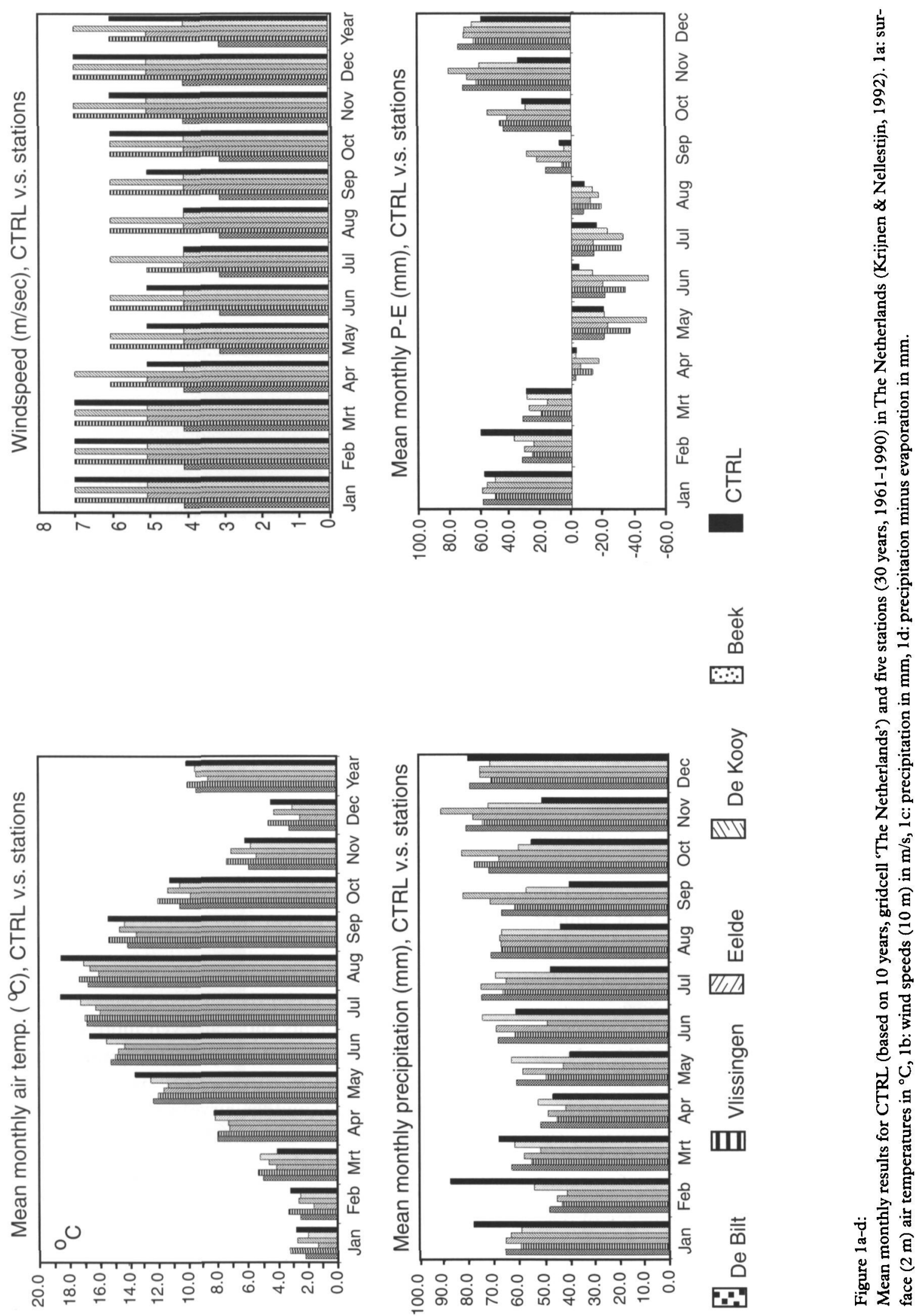

sults for monthly precipitation and that it is preferred to consider the yearly averages when analysing PBexp and YDexp. Moreover, the frequency of occurrence of days without precipitation (i.e. less than $0.1 \mathrm{~mm}$,
$27 \%$ ) and with $10 \mathrm{~mm}$ or more $(3 \%)$ is less in the model than observed ( 31 to $37 \%$ and 5 to $6 \%$ respectively, Table 2). However, the simulated frequency of days with snowfall $(10 \%)$ is in agreement with the 
Table 2. Frequency of extremes for CTRL, PBexp, YDexp and five stations in The Netherlands (Krijnen \& Nellestijn, 1992). The simulation results are based on 10 model years, whereas the station data are for the reference period 1961-1990. Please note that the frequencies are expressed as percentages to facilitate model-data comparison, since a model year consists of 360 days instead of 365 .

\begin{tabular}{|c|c|c|c|c|c|c|c|}
\hline & $\begin{array}{l}\text { Days/yr } \\
\text { Tmean } \\
<0^{\circ} \mathrm{C} \\
{[\%]}\end{array}$ & $\begin{array}{l}\text { Days/yr } \\
\text { Tmin } \\
<-10^{\circ} \mathrm{C} \\
{[\%]}\end{array}$ & $\begin{array}{l}\text { Days/yr } \\
T \max \\
\geq 25^{\circ} \mathrm{C} \\
{[\%]}\end{array}$ & $\begin{array}{l}\text { Days/yr } \\
\text { Wind sp. } \geq \\
6 \mathrm{Bft}(10.8 \mathrm{~m} / \mathrm{s}) \\
{[\%]}\end{array}$ & $\begin{array}{l}\text { Days } / \mathrm{yr} \\
\text { Precip } \\
\geq 10 \mathrm{~mm} \\
{[\%]}\end{array}$ & $\begin{array}{l}\text { Days/yr } \\
\text { with } \\
\text { No Precip } \\
{[\%]}\end{array}$ & $\begin{array}{l}\text { Days/yr } \\
\text { with } \\
\text { snowfall } \\
{[\%]}\end{array}$ \\
\hline De Bilt & 7 & 1 & 5 & 2 & 6 & 32 & 8 \\
\hline Vlissingen & 4 & 0 & 2 & 29 & 5 & 37 & 6 \\
\hline Eelde & 9 & 2 & 4 & 11 & 5 & 31 & 10 \\
\hline De Kooy & 5 & 1 & 1 & 33 & 5 & 35 & 8 \\
\hline Beek & 8 & 1 & 6 & 8 & 5 & 31 & 10 \\
\hline CTRL & 5 & 0 & 4 & 9 & 3 & 27 & 10 \\
\hline PBexp & 13 & 2 & 13 & 3 & 3 & 28 & 19 \\
\hline YDexp & 38 & 16 & 1 & 12 & 2 & 13 & 41 \\
\hline
\end{tabular}

values for the inland stations of Eelde and Beek (see Table 2). Despite the imperfect simulation of precipitation, most simulated monthly P-E values fall within the range of data provided for the five stations (Fig 1d). A surplus in effective precipitation is shown for the period September to March, whereas negative P$\mathrm{E}$ values are recorded for April to August. The model overestimates the value for February, but underestimates values for June and November. The mean annual P-E sum $(227 \mathrm{~mm}$ ) falls in the range of the station estimates that vary from 138 to $260 \mathrm{~mm}$.

\section{Summary of model performance for modern climate}

The model performance for the present climate may be summarised as follows:

- The mean monthly surface temperatures are generally well simulated, with the exception of summer temperatures that are overestimated compared to station data. The frequency of certain temperature extremes is also well reproduced.

- The mean monthly wind speeds and the frequency of high wind-speed events are of the right order of magnitude.

- The mean annual precipitation is slightly underestimated; the monthly precipitation values are overestimated during winter and underestimated during summer.

- The amount of snowfall and the frequency of days with snowfall match with observations.

- The monthly and annual mean P-E values generally correspond with station estimates.

\section{$P B$ and $Y D$ climates}

\section{Temperature}

A comparison of the mean monthly temperatures of the three experiments reveals significant differences.
In PBexp, the seasonality (i.e. difference between summer and winter season) seems to be larger compared to CTRL (see Fig. 2a). The mean monthly temperatures of the winter half year (October to March) are substantially lower (January temperature $-0.1^{\circ} \mathrm{C}$ and max. PBexp-CTRL difference $3.3^{\circ} \mathrm{C}$ ), whereas the summer values are higher than in CTRL, reaching $21.0^{\circ} \mathrm{C}$ in July (max. PBexp-CTRL difference $2.4^{\circ} \mathrm{C}$ ). However, as the anomaly for the summer half year is somewhat smaller than for winter, the net result is that the mean annual temperature is slightly lower in PBexp (only $0.4^{\circ} \mathrm{C}$ ) than in CTRL. Compared to PBexp, the mean monthly temperatures for YDexp are 5 to $8^{\circ} \mathrm{C}$ lower throughout the year. The difference in mean annual temperatures is $7^{\circ} \mathrm{C}$. In summer, the highest monthly value in YDexp is $14.1^{\circ} \mathrm{C}$ (July), whereas in winter it goes down to $-8.2^{\circ} \mathrm{C}$ (January).

As expected, the mean daily temperature curves for the three experiments show an even more expressed difference in the annual temperature range than the monthly temperature curves (Figs. 3a-c). The mean daily temperature (middle curve) represents the average of 10 values, as 10 annual cycles are considered. In CTRL the annual range in average daily temperature is $19.8^{\circ} \mathrm{C}$, whereas in PBexp and YDexp the values are $25.3^{\circ} \mathrm{C}$ and $31.6^{\circ} \mathrm{C}$ respectively. Besides the mean daily values, also the minimum and maximum daily temperatures are plotted in Figure 3 to give an impression of the inter-annual range in mean daily temperatures. Please note that these minimum and maximum values are the extremes of the mean daily temperatures and differ from the absolute minimum and maximum temperatures. The difference between the minimum and maximum curves is in the summer half year typically in the range of 4 to $8^{\circ} \mathrm{C}$. In all ex- 

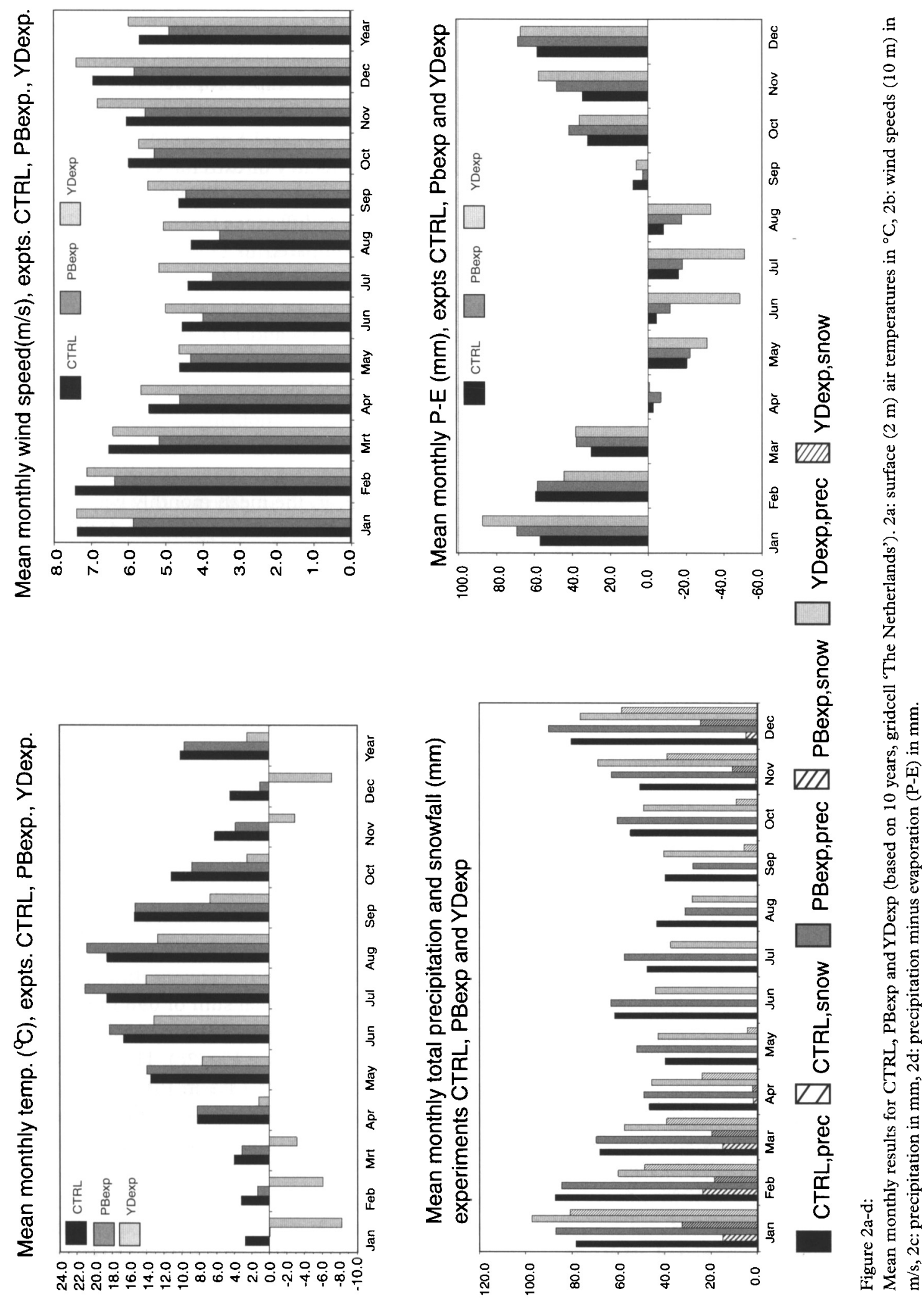

periments, this difference between the extreme curves is larger during winter, revealing more inter-annual variability. However, the curves for YDexp show a marked inter-annual variability for winter that exceeds that of PBexp considerably. For instance, for some days in January a mean daily temperature of $+2^{\circ} \mathrm{C}$ is simulated in one year (upper curve Fig. 3c), while in another year it is below $-40^{\circ} \mathrm{C}$ (lower curve). An analysis of the 'raw' results shows that also a strong day-to-day variability is involved, as in many cases the daily temperatures jump within a few days from $-30^{\circ} \mathrm{C}$ to $+1^{\circ} \mathrm{C}$. This analysis has also shown 
Mean daily temp ( $\left.{ }^{\circ} \mathrm{C}\right)$ CTRL: mean, min, max

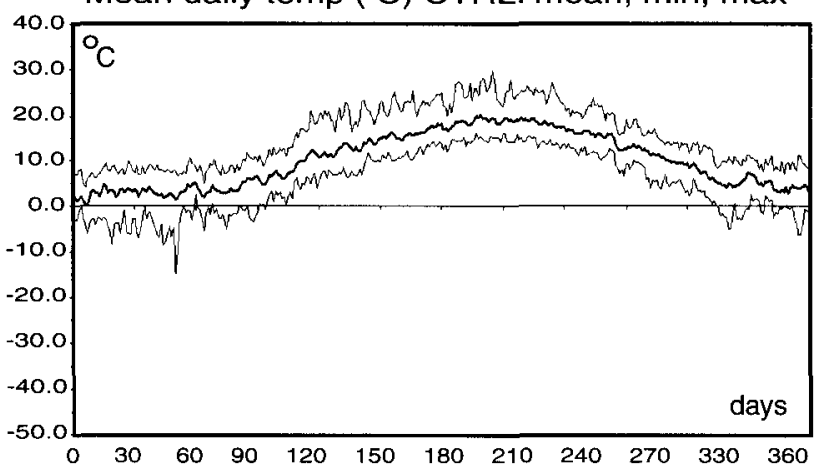

Mean daily temp $\left({ }^{\circ} \mathrm{C}\right)$ PBexp: mean, min, max

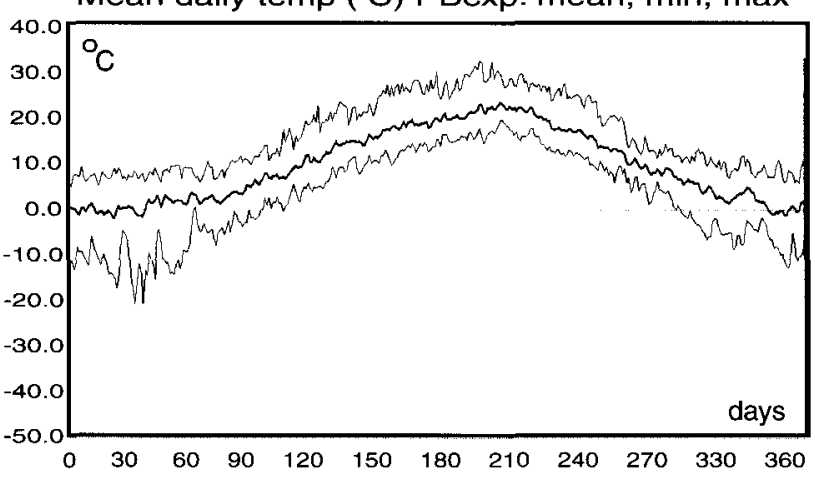

Mean daily temp $\left({ }^{\circ} \mathrm{C}\right)$ YDexp: mean, min, max

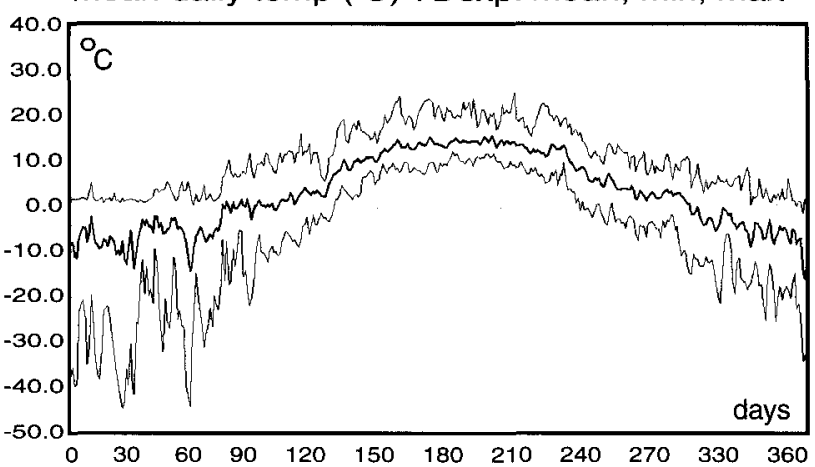

Figure 3a-c:

Annual cycle of mean daily temperatures (bold middle curve, mean of 10 days) and extremes: minimum (lower curve) and maximum (upper curve), values of days out of 10 with lowest or highest mean daily temperatures. 3a) CTRL, 3b) PBexp, 3c) YDexp.

that the variability is probably associated with the passage of depressions, as the jumps in temperature are accompanied by increases in precipitation. During the passage of a depression, the source region of the air masses changes, as typically just before a depression relatively warm and moist air is transported with SW winds from the ice-free Atlantic towards Europe. This warm and moist flow interrupts the transport of cold and dry air originating from the (partly) ice covered northernmost Atlantic Ocean and Nordic seas. An analysis of day-to-day variability of wind direction has revealed that the frequency of cold easterly winds is lower in YDexp compared to PBexp and CTRL (not shown).

The simulated frequency of extreme events (Table 2) in YDexp and PBexp supports the notion of a well-expressed temperature difference for the $\mathrm{YD}$ and $\mathrm{PB}$ climatic regimes. Compared to YDexp, the occurrence of days with frost (mean temperature $<0^{\circ} \mathrm{C}$ ) and with 'severe' frost (minimum temperature $<-10^{\circ} \mathrm{C}$ ) is in PBexp reduced by $25 \%$ and $14 \%$ respectively. On the other hand, the frequency of days with maximum temperatures of $25^{\circ} \mathrm{C}$ or more increases substantially $(+12 \%)$.

Winds

Throughout the year, the mean monthly wind speeds are substantially lower in PBexp than in CTRL and YDexp (Fig. 2b). Compared to YDexp, the mean difference is more than $1 \mathrm{~m} / \mathrm{s}$, implying that on average winds in YDexp (yearly mean $6.0 \mathrm{~m} / \mathrm{s}$ ) are about $20 \%$ stronger than in PBexp (yearly mean $4.9 \mathrm{~m} / \mathrm{s}$ ). The difference in wind climate between the two experiments is also expressed in the frequency of days with wind strength reaching $6 \mathrm{Bft}$ (i.e. $10.8 \mathrm{~m} / \mathrm{s}$ ), which is $3 \%$ in PBexp and $12 \%$ in YDexp (compared to $9 \%$ in CTRL, see Table 2). In YDexp, the winds are relatively strong during summer (when minimum values are found for CTRL and PBexp) and resemble what is seen during autumn in CTRL. The minimum mean monthly wind speeds in YDexp are recorded in May $(4.6 \mathrm{~m} / \mathrm{s})$.

\section{Precipitation, snowfall and $P-E$}

Compared to CTRL (annual sum of $698 \mathrm{~mm}$ ), more precipitation is simulated in PBexp $(735 \mathrm{~mm})$ and less in YDexp (647 mm, see Fig. 2c). This implies an increase in precipitation of $14 \%$ in PBexp compared to YDexp. In addition, as shown in Table 2, the frequency of days with $\geq 10 \mathrm{~mm}$ precipitation is slightly less in YDexp (2\%) than in PBexp (3\%). However, in YDexp the precipitation seems to be more evenly distributed over the year, as the number of days without precipitation (13\%) is substantially lower than in PB$\exp (28 \%)$. As expected from the simulated temperature regimes, snowfall is in both PBexp and YDexp much more common than in CTRL (see Fig 2c). Nearly half of the simulated precipitation $(48 \%)$ in YDexp falls as snow (i.e. $308 \mathrm{~mm}$ ). In PBexp this percentage is still $15 \%(107 \mathrm{~mm})$, compared to $9 \%$ in CTRL $(61 \mathrm{~mm})$. Moreover, the frequency of days with snowfall observed in CTRL $(10 \%)$ is nearly doubled in PBexp (19\%) and quadrupled in YDexp 
( $41 \%$, see Table 2$)$. In the latter experiment snowfall is only absent from June to August (Fig. 2c). The trend in simulated P-E is the same as noted for the precipitation, as - compared to CTRL - the values are higher in PBexp and lower in YDexp. The yearly sums are as follows: $227 \mathrm{~mm}$ (CTRL), $251 \mathrm{~mm}$ (PBexp) and $173 \mathrm{~mm}$ (YDexp). Consequently, the YDexp-PBexp difference in P-E (45\%) is much more substantial than in precipitation (14\%). This can be attributed to the distinct negative P-E values simulated in summer in YDexp (see Fig. 2d).

\section{Discussion and conclusions}

The presented simulations suggest the following changes in climate during the YD-PB transition in The Netherlands:

- An increase in monthly temperatures ranging from 5 to $8^{\circ} \mathrm{C}$ and in mean annual values of $7^{\circ} \mathrm{C}$.

- A decrease in the annual range of mean daily temperatures (in the model from $31.6^{\circ} \mathrm{C}$ in YDexp to $25.3^{\circ} \mathrm{C}$ in PBexp).

- A $20 \%$ reduction in monthly mean wind speed and a four-fold decrease in the frequency of strong wind events.

- An increase in mean annual values of precipitation $(14 \%)$ and effective precipitation (more than $40 \%)$.

- More frequent heavy rain events and a doubling of the number of days without precipitation. In other words, in PB more precipitation is falling in fewer days.

- A strong decrease in the amount of snowfall (more than $60 \%$ ) and a $50 \%$ reduction in the frequency of days with snowfall.

\section{To what extent are these changes realistic?}

One could argue that the YDexp-PBexp difference is not seriously biased by model deficiencies, at least if it is assumed that the errors described for CTRL (sect. 3.1) are equally present in YDexp and PBexp (cf. Isarin \& Renssen, 1999). Accepting this assumption still leaves uncertainties related to the prescribed boundary conditions. Therefore, it is very useful to evaluate the validity of the simulated changes by reviewing their consistency with proxy records.

A comparison of simulated temperatures with reconstructions in an earlier study suggested that the YD winters and PB summers in The Netherlands were colder than suggested by YDexp and PBexp (Renssen $\&$ Isarin, 2001). The results for the YD summers and PB winters were similar in model results and recon- structions. Proxy data suggest for the YD a mean winter temperature of $-20^{\circ} \mathrm{C}$ for The Netherlands as opposed to $-7^{\circ} \mathrm{C}$ to $-8^{\circ} \mathrm{C}$ in YDexp. The model-data mismatch was explained by the position of the sea-ice margin, as this was probably located at $52^{\circ} \mathrm{N}$ instead of the $55-60^{\circ} \mathrm{N}$ prescribed in YDexp (Renssen \& Isarin, 1998). This is supported by a simulation with Late Pleni-glacial boundary conditions (including an expanded winter sea-ice cover at $50^{\circ} \mathrm{N}$ ) that produced winter temperatures of $-20^{\circ} \mathrm{C}$ in NW Europe (Renssen \& Isarin, 2001). As a consequence, the winter temperature increase over the YD-PB transition was probably at least twice the suggested $8^{\circ} \mathrm{C}$. Moreover, it is most likely that the amount of snow fall is also underestimated, since in YDexp still a small proportion of the winter precipitation is falling as rain (see Fig. 2c). Assuming that the YD winter temperatures were much lower than the simulated $-7^{\circ} \mathrm{C}$ to $-8^{\circ} \mathrm{C}$, it is likely that in the YD most precipitation in November to April was in the form of snow, so that a snow pack was covering the surface during half of the year. Consequently, probably the amount of snowfall decreased even more over the YD-PB transition than the simulated $60 \%$. On the other hand, since evaporation was lower during YD winters than suggested by the anomalously warm YDexp, the difference in P-E sum between YD and $\mathrm{PB}$ is probably lower than the $40 \%$ increase suggested by the model (assuming that precipitation is reasonably simulated). The reconstructions based on proxy data suggest that PBexp overestimates $\mathrm{PB}$ summer temperatures in The Netherlands by 1 to $2^{\circ} \mathrm{C}$. In short, probably the increase in summer temperatures over the YD-PB transition is less than the simulated $5^{\circ} \mathrm{C}$, whereas the increase in winter temperatures is more than suggested by the experiments.

The simulated increase in precipitation and P-E is in agreement with the inferred rise in lake levels during the early PB (Bohncke \& Wijmstra, 1988; Bohncke, 1993). Moreover, the calculated decrease in wind strength and in frequency of high wind speed events is consistent with the decrease in aeolian activity inferred for the YD-PB transition (e.g., Vandenberghe, 1991; Kasse, 1995). It should be noted that proxy data suggest that the YD may be divided in an earlier wetter part and a drier second part (e.g., Bohncke et al., 1988; 1993; Bohncke and Vandenberghe, 1991; Vandenberghe, 1995; Renssen et al., 2000b). Moreover, the early PB is also subdivided by palaeo-ecologists in the Friesland (relatively warm) and Rammelbeek (relatively cold or continental) phases (e.g., Wijmstra \& de Vin, 1971; van Geel et al., 1980/1981). However, as already noted, the relatively poor tempo- 
ral resolution of the boundary conditions did not enable us to make these distinctions.

\section{Are the simulated changes consistent with prescribed boundary conditions?}

The two most important boundary conditions are insolation and the state of the ocean surface. The large increase in seasonality in PBexp compared to CTRL can be attributed to insolation changes. As mentioned earlier, the insolation values were very different from today, with higher values during summer (more than $30 \mathrm{~W} / \mathrm{m}^{2}$ difference) and lower values during winter (about $10 \mathrm{~W} / \mathrm{m}^{2}$ difference) (Berger, 1978). The model response in PBexp is similar to results of simulations in which only the insolation of $6 \mathrm{cal} \mathrm{ky} \mathrm{BP}$ was changed compared to today (e.g., Texier et al., 1997). The prescribed insolation in YDexp is not very different from that in PBexp, suggesting that other boundary conditions were the main driving factors behind the YDexp-PBexp anomalies. The most important difference between the two experiments is the state of the N Atlantic Ocean, as the change in other boundary conditions was relatively small (see Table 2). In PBexp the ocean surface conditions are equal to those in CTRL, whereas in YDexp the Atlantic was cooled by more than $8^{\circ} \mathrm{C}$, leading to a sea-ice cover north of $55-60^{\circ} \mathrm{N}$ in winter. This sea ice cover enhanced the seasonality in YDexp even further. In winter, the air cooled to temperatures below $-35^{\circ} \mathrm{C}$ over the sea-ice cover (i.e. $>30^{\circ} \mathrm{C}$ difference compared to CTRL), whereas in summer the ocean was ice free up to $70^{\circ} \mathrm{N}$ with SSTs $8^{\circ} \mathrm{C}$ lower than today (Renssen, 1997). This strong seasonal contrast was also experienced in W Europe, as during the YD a westerly atmospheric circulation was prevailing (Renssen et al., 1996; Isarin et al., 1997). Moreover, the strong cooling over the extended sea ice steepened the meridional temperature gradient, causing an intensification of the westerlies in YDexp. This explains the noted relatively high wind speeds in YDexp. In PBexp, relatively weak winds are simulated, even compared to CTRL. This difference that may be attributed to the more continental setting of The Netherlands in PBexp. The roughness length (i.e. resistance experienced by air flow) is much larger over land surfaces than over the oceans, causing the winds to be stronger in The Netherlands in CTRL than in PBexp due to the vicinity of the North Sea in the former experiment (cf. Isarin et al. 1997).

What caused the YDexp-PBexp changes in precipitation and P-E? Renssen et al. (1996) have shown that in winter the main depression track was displaced southward from about $60^{\circ} \mathrm{N}$ (today) to $55^{\circ} \mathrm{N}$ (YD), following the main temperature gradient along the sea ice margin. Together with the strengthening of the westerlies, this would bring more frequently depressions towards W Europe in YDexp than in PBexp. However, in YDexp lower precipitation values are simulated despite these more frequent depressions. This may be explained by the fact that in YDexp a substantial part of the Atlantic Ocean was not available as a moisture source because of the extended sea ice cover. Moreover, the low temperatures in YDexp lowered the moisture-holding capacity of the air. Consequently, the latter two factors caused the air to be relatively dry in YDexp compared to PBexp. The parameterisation of permafrost applied in YDexp influenced the P-E fluxes substantially. Part of this parameterisation is the constant high ground water table in areas with permafrost (including The Netherlands), providing an unlimited moisture source in summer (Renssen et al., 2000a). The latter effect produced, together with the relatively strong winds, high evaporation values in YDexp, explaining the strong negative P-E fluxes in summer in Figure $2 d$.

\section{Concluding remarks}

Our model suggests the following characteristics for the YD and PB climates in The Netherlands. The YD climate is characterised by cold winters (daily temperatures frequently under $-20^{\circ} \mathrm{C}$ ) under influence of the sea-ice covered $\mathrm{N}$ Atlantic, whereas the summers were already quite mild (daily temperatures over $13^{\circ} \mathrm{C}$ ) because of the relatively high insolation values. Furthermore, a strong interannual and day-to-day variability is simulated with strong fluctuations of temperatures, frequent storms and snowfall from September to May. The inferred YD temperature regime is today found in northern Russia, for example in Nar'yan Mar (Pechora delta, 67 $39^{\prime} \mathrm{N}, 53^{\circ} 01^{\prime} \mathrm{E}$ ), with mean annual, January and July temperatures of $-3.9^{\circ} \mathrm{C},-17.3^{\circ} \mathrm{C}$ and $12.0^{\circ} \mathrm{C}$, respectively (Lydolph, 1977). However, at this location the climate is much drier, with an annual precipitation sum of only 378 $\mathrm{mm}$. The PB climate was a 'continental' version of present climate, with warmer summers and cooler winters $\left(\sim 2^{\circ} \mathrm{C}\right.$ difference in both seasons compared to today), more snowfall, but lower wind speeds. In addition, the PB climate was probably wetter than the present climate. Today, a similar climate is found in eastern Europe, for example in Simferopol (Southern Ukraine, $45^{\circ} 01^{\prime} \mathrm{N}, 33^{\circ} 59^{\prime} \mathrm{E}$ ) with mean annual, January and July temperatures of $9.8^{\circ} \mathrm{C},-0.7^{\circ} \mathrm{C}$ and $20.6^{\circ} \mathrm{C}$, respectively, and an annual precipitation sum of $768 \mathrm{~mm}$ (Lydolph, 1977). Considering that the 
transition between these very different climates occurred within 50 years, it is indeed expected that the changes had a large impact on the environment in The Netherlands. Fortunately, these changes during the YD-PB transition are incomparable to the gradual and small climate changes that we are experiencing today.

\section{Acknowledgements}

The useful comments of Prof. C.J.E. Schuurmans, Dr. A. Veldkamp and Dr. B. van Geel are gratefully acknowledged. This study is supported by the Dutch National Research Programme on Global Air Pollution and Climate Change (contract number 951245).

\section{References}

Adams, J., 1997. Europe during the last 150,000 years, Environmental Sciences Division, Oak Ridge National Laboratory, at www.ornl.gov

Barnola, J.M., Raynaud, D., Korotkevich, Y.S. \& Lorius, C., 1987. Vostok ice core provides 160,000 -year record of atmospheric $\mathrm{CO}_{2}$. Nature: 329, 408-414.

Berger, A.L., 1978. Long-term variations of daily insolation and Quaternary climatic changes. Journal of the Atmospheric Sciences: 35, 2363-2367.

Blunier, T., Chappellaz, J., Schwander, J., Stauffer, B. \& Raynaud, D., 1995. Variations in atmospheric methane concentration during the Holocene epoch. Nature: 374, 46-49.

Bohncke, S.J.P., 1993. Lateglacial environmental changes in The Netherlands: spatial and temporal patterns. Quaternary Science Reviews: 12, 707-717.

Bohncke, S.J.P., and Vandenberghe, J., 1991. Palaeohydrological development in the Southern Netherlands during the last 15000 years. In: Starkel, L., Gregory, K.J., and Thornes, J.B. (eds.): Temperate palaeohydrology. John Wiley and Sons Ltd. (Wichester), pp. 253-281.

Bohncke, S.J.P. \& Wijmstra, L., 1988. Reconstruction of LateGlacial lake-level fluctuations in The Netherlands based on palaeobotanical analyses, geochemical results and pollen density data. Boreas: 17, 403-425.

Bohncke, S., Vandenberghe, J., Coope, R. \& Reiling, R., 1987. Geomorphology and palaeoecology of the Mark valley (southern Netherlands): palaeoecology, palaeohydrology and climate during the Weichselian Late Glacial. Boreas: 16, 69-85.

Bohncke, S.J.P., Vandenberghe, J. \& Huijzer, A.S., 1993. Periglacial environments during the Weichselian Late Glacial in the Maas Valley, The Netherlands. Geologie en Mijnbouw: 72, 193-210.

Bogaart, P.W., and van Balen, R.T., 2000. Numerical modeling of the response of alluvial rivers to Quaternary climate change. Global and Planetary Change: 27, 147-163.

Brauer, A., Endres, C., Günter, C., Litt, T., Stebich, M. \& Negendank, J.F.W., 1999. High resolution sediment and vegetation responses to Younger Dryas climate change in varved lake sediments from Meerfelder Maar, Germany. Quaternary Science Reviews: 18, 321-329.

Claussen, M., Lohmann, U., Roeckner, E. \& Schulzweida, U., 1994. A global data set of land-surface parameters. Max-PlanckInstitut für Meteorologie (Hamburg) Report 135, 30 pp.

Cleveringa, P., de Gans, W., Kolstrup, E. \& Paris, F.P., 1977. Vege- tational and climatic developments during the Late Glacial and the early Holocene and acolian sedimentation as recorded in the Uteringsveen (Drente, The Netherlands). Geologie en Mijnbouw: 56, 234-242.

de Groot, T., Cleveringa, P. \& Klijnstra, B., 1987. Frost-mound scars and the evolution of a Late Dryas environment (Northern Netherlands). Geologie en Mijnbouw: 66, 239-250.

DKRZ, 1994. The ECHAM 3 Atmospheric General Circulation Model. Deutsches Klimarechenzentrum (Hamburg), Technical report no. 6: $184 \mathrm{pp}$.

Fairbanks, R.G., 1989. A 17,000-year glacio-eustatic sea level record: influence of glacial melting rates on the Younger Dryas event and deep-ocean circulation. Nature: 342, 637-642.

Flückiger, J., Dällenbach, A., Blunier, T., Stauffer, B., Stocker, T.F., Raynaud, D. \& Barnola, J.-M., 1999. Variations in Atmospheric $\mathrm{N}_{2} \mathrm{O}$ concentration during abrupt climatic changes. Science: 285, 227-230.

Hoek, W.Z., 1997a. Late-glacial and early Holocene climatic events and chronology of vegetation development in The Netherlands. Vegetation History and Archaeobotany: 6, 197-213.

Hoek, W.Z., 1997b. Palaeogeography of Lateglacial vegetations. Netherlands Geographical Studies 230: $147 \mathrm{pp}$.

Huisink, M., 1997. Late-glacial sedimentological and morphological changes in a lowland river in response to climatic change: the Maas, southern Netherlands. Journal of Quaternary Science: 12, 209-223.

Isarin, R.F.B., 1997. Permafrost distribution and temperatures in Europe during the Younger Dryas. Permafrost and Periglacial Processes: 8, 313-333.

Isarin, R.F.B. \& Bohncke, S.J.P., 1999. Mean July temperatures during the Younger Dryas in Northwestern and Central Europe as inferred from climate indicator plant species. Quaternary Research: 51, 158-173.

Isarin, R.F.B. \& Renssen, H., 1999. Reconstructing and modelling Late Weichselian climates: the Younger Dryas in Europe as a case study. Earth-Science Reviews: 48, 1-38.

Isarin, R.F.B., Renssen, H. \& Koster, E.A., 1997. Surface wind climate during the Younger Dryas in Europe as inferred from aeolian records and model simulations. Palaeogeography, Palaeoclimatology, Palaeoecology: 134, 127-148.

Kallel, N., Labeyrie, L.D., Arnold, M., Okada, H., Dudleyn, W.C. \& Duplessy, J.C., 1988. Evidence of cooling during the Younger Dryas in the western North Pacific. Oceanologica Acta: 11, 369375.

Kasse, C., 1995a. Younger Dryas cooling and fluvial response (Maas River, The Netherlands). Geologie en Mijnbouw: 74, 251-256.

Kasse, C., 1995b. Younger Dryas climatic changes and aeolian depositional environments. In: Troelstra, S.R., van Hinte, J.E., \& Ganssen, G.M., (eds.): The Younger Dryas. KNAW Verhandelingen, Afd. Natuurkunde, Eerste Reeks, deel 44. North-Holland Publishers (Amsterdam): 27-31.

Koç, N., Jansen, E. \& Haflidason, H., 1993. Paleoceanographic reconstructions of surface ocean conditions in the Greenland, Iceland and Norwegian Seas through the last $14 \mathrm{ka}$ based on diatoms. Quaternary Science Reviews: 12, 115-140.

Krijnen, H.J. \& Nellestijn, J.W. (eds.), 1992. Klimatologische gegevens van Nederlandse stations: normalen en extreme waarden van de 15 hoofdstations voor het tijdvak 1961-1990. KNMI publication 150-27 (De Bilt), 159 pp.

Leeder, M.R., Harris, T., \& Kirkby, M.J., 1998. Sediment supply and climate change: implications for basin stratigraphy. Basin Research: 10, 7-18.

Lydolph, P.E., 1977. Climates of the Sovjet Union. Elsevier (Amsterdam), 443 pp. 
Maarleveld, G.C. \& van der Schans, R.P.H.P., 1961. De dekzandmorfologie van de Gelderse Vallei. Tijdschrift van het Koninklijk Nederlandsch Aardrijkskundig Genootschap: 78, 22-34.

Mikolajewicz, U., Crowley, T.J., Schiller, A. \& Voss, R., 1997. Modelling teleconnections between the North Atlantic and North Pacific during the Younger Dryas. Nature: 387, 384-387.

Peltier, W.R., 1994. Ice age paleotopography. Science: 265, 195201.

Raynaud, D., Jouzel, J., Barnola, J.M., Chappellaz, J., Delmas, R.J. \& Lorius, C., 1993. The ice record of greenhouse gases. Science: 259, 926-933.

Renssen, H., 1997. The global response to Younger Dryas boundary conditions in an AGCM simulation. Climate Dynamics: 13, 587-599.

Renssen, H. \& Isarin, R.F.B., 1998. Surface temperature in NW Europe during the Younger Dryas: AGCM simulation compared with temperature reconstructions. Climate Dynamics: 14, 33-44.

Renssen, H. \& Isarin, R.F.B., 2001. The two major warming phases of the last deglaciation at $\sim 14.7$ and $\sim 11.5 \mathrm{kyr}$ cal BP in Europe: climate reconstructions and AGCM experiments. Global and Planetary Change, in press.

Renssen, H. \& Lautenschlager, M., 2000. The effect of vegetation in a climate model simulation on the Younger Dryas. Global and Planetary Change: $26,423-443$.

Renssen, H., Isarin, R.F.B., Vandenberghe, J., Lautenschlager, M. \& Schlese, U., 2000a. Permafrost as a critical factor in palaeoclimate modelling: the Younger Dryas case in Europe. Earth and Planetary Science Letters: 176, 1-5.

Renssen, H., Lautenschlager, M. \& Schuurmans, C.J.E., 1996. The atmospheric winter circulation during the Younger Dryas stadial in the Atlantic/European sector. Climate Dynamics: 12, 813824.

Renssen, H., van Geel, B., van der Plicht, J. \& Magny, M., 2000b. Reduced solar activity as a trigger for the start of the Younger Dryas? Quaternary International: 68-71, 373-383.

Roeckner, E., Arpe, K., Bengtsson, L., Christoph, M., Claussen, M., Dümenil, L., Esch, M., Giorgetta, M., Schlese, U. \& Schulzweida, U., 1996. The atmospheric general circulation model ECHAM-4: model description and simulation of presentday climate. Max-Planck-Institut für Meteorologie (Hamburg), Report no. 218: 90 pp.

Sarnthein, M., Jansen, E., Weinelt, M., Arnold, M., Duplessy, J.C., Erlenkeuser, H., Flatøy, A., Johannessen, G., Johannessen, T., Jung, S., Koc, N., Labeyrie, L., Maslin, M., Pflaumann, U. \& Schulz, H., 1995. Variations in Atlantic surface ocean paleo- ceanography, $50^{\circ}-80^{\circ} \mathrm{N}$ : A time-slice record of the last 30,000 years. Paleoceanography: 10, 1063-1094.

Schiller, A., Mikolajewicz, U. \& Voss, R., 1997. The stability of the North Atlantic thermohaline circulation in a coupled ocean-atmosphere general circulation model. Climate Dynamics: 13, 325-347.

Schulz, H., 1995. Meeresoberflächentemperaturen vor 10.000 Jahren - Auswirkungen des frühholozänen Insolationsmaximum. Geologisches-Paläontologische Institut Universität Kiel Report $73,156 \mathrm{pp}$

Taylor, K.C., Lamorey, G.W., Doyle, G.A., Alley, R.B., Grootes, P.M., Mayewski, P.A., White, J.W.C. \& Barlow, L.K., 1993. The "flickering switch" of late Pleistocene climate change. Nature: $361,432-436$.

Texier, D., de Noblet, N., Harrison, S.P., Haxeltine, A., Jolly, D., Joussaume, S., Laarif, F., Prentice, I.C., and Tarasov, P., 1997. Quantifying the role of biosphere-atmosphere feedbacks in climate change: coupled model simulations for 6000 years BP and comparison with palaeodata for northern Eurasia and northern Africa. Climate Dynamics: 13, 865-882.

Thunell, R.C. \& Miao, Q.M., 1996. Sea surface temperatures of the Western Equatorial Pacific Ocean during the Younger Dryas. Quaternary Research: 46, 72-77.

Vandenberghe, J., Bohncke, S., Lammers, W. \& Zilverberg, L., 1987. Geomorphology and palaeoecology of the Mark valley (southern Netherlands): geomorphological valley development during the Weichselian and Holocene. Boreas: 16, 55-67.

Vandenberghe, J., 1991. Changing conditions of aeolian sand deposition during the last deglaciation period. Zeitschrift für Geomorphologie: Supplement Band 90, 193-207.

Vandenberghe, J., 1995. The climate of the Younger Dryas in The Netherlands. Geologie en Mijnbouw: 74, 245-249.

van der Hammen, T., 1952. Late-Glacial flora and periglacial phenomena in The Netherlands. Leidse Geologische Mededelingen: $17,71-184$.

van Geel, B., Bohncke, S.J.P. \& Dee, H., 1980/1981. A palaeoecological study of an upper Late Glacial and Holocene sequence from "de Borchert", The Netherlands. Review of Palaeobotany and Palynology: 31, 367-448.

Weerts, H.J.T. \& Berendsen, H.T.A., 1995. Late Weichselian and Holocene fluvial palaeogeography of the southern Rhine-Meuse delta (The Netherlands). Geologie en Mijnbouw 74: 199-212.

Wijmstra, T.A. \& de Vin, E., 1971. The new Dinkel canal section. Mededelingen Rijks Geologische Dienst Nieuwe Serie: 22, 101 129. 